NBER WORKING PAPER SERIES

\title{
CORPORATE GOVERNANCE AND THE DEVELOPMENT OF MANUFACTURING ENTERPRISES IN NINETEENTH-CENTURY MASSACHUSETTS
}

\author{
Eric Hilt \\ Working Paper 20096 \\ http://www.nber.org/papers/w20096 \\ NATIONAL BUREAU OF ECONOMIC RESEARCH \\ 1050 Massachusetts Avenue \\ Cambridge, MA 02138 \\ May 2014
}

I would like to thank Jeremy Atack, Carola Frydman, Robert Margo and William Collins for helpful comments. The views expressed herein are those of the author and do not necessarily reflect the views of the National Bureau of Economic Research.

NBER working papers are circulated for discussion and comment purposes. They have not been peerreviewed or been subject to the review by the NBER Board of Directors that accompanies official NBER publications.

(C) 2014 by Eric Hilt. All rights reserved. Short sections of text, not to exceed two paragraphs, may be quoted without explicit permission provided that full credit, including $\odot$ notice, is given to the source. 
Corporate Governance and the Development of Manufacturing Enterprises in Nineteenth-Century Massachusetts

Eric Hilt

NBER Working Paper No. 20096

May 2014

JEL No. D23,K2,N11

\begin{abstract}
This paper analyzes the use of the corporate form among nineteenth-century manufacturing firms in Massachusetts, from newly collected data from 1875. An analysis of incorporation rates across industries reveals that corporations were formed at higher rates among industries in which firm size was larger. But conditional on firm size, the industries in which production was conducted in factories, rather than artisanal shops, saw more frequent use of the corporate form. On average, the ownership of the corporations was quite concentrated, with the directors holding 45 percent of the shares. However, the corporations whose shares were quoted on the Boston Stock Exchange were 'widely held' at rates comparable to modern American public companies. The production methods utilized in in different industries also influenced firms' ownership structures. In many early factories, steam power was combined with unskilled labor, and managers likely performed a complex supervisory role that was critical to the success of the firm. Consistent with the notion that monitoring management was especially important among such firms, corporations in industries that made greater use of steam power and unskilled labor had more concentrated ownership, higher levels of managerial ownership, and smaller boards of directors.
\end{abstract}

Eric Hilt

Wellesley College

Department of Economics

106 Central Street

Wellesley, MA 02481

and NBER

ehilt@wellesley.edu 


\section{Introduction}

The ownership structure of public corporations in the United States today is unique. Relative to those of other countries, American corporations are less likely to have a parent company or be part of a family business group, and more likely to be widely held (LaPorta et al, 1999). The historical origins of the distinctive patterns of corporate ownership in the United States are widely debated, and a number of competing explanations have been offered, ranging from populist politics (Roe, 2004) to the protections of investors resulting from the early origins of the American legal system (LaPorta et al, 1998). But the historical evolution of corporate ownership in the United States is poorly documented, and the timing of the emergence of the distinctively American style of corporate ownership, along with the factors that may have been responsible for its emergence, are not well understood.

Most accounts of the history of American corporate ownership tend to echo the influential work of Berle and Means (1932), who argue that prior to the rise of big business' around the turn of the twentieth century, American industrial corporations were owned by limited numbers of investors who participated actively in the governance of their firms. ${ }^{1}$ More recent work has challenged this view, arguing from early nineteenth century data that the separation of ownership from control occurred much earlier (Hilt, 2008). The contradictory and fragmentary findings of this literature reflect the frustrating scarcity of data on early American corporations, particularly industrial firms, which were subject to relatively few disclosure requirements in most states' corporation laws.

This paper presents new, comprehensive data on the ownership and governance of industrial corporations from the third quarter of the nineteenth century-before the rise of big business'-from the State of Massachusetts. At the time, Massachusetts was among the most

\footnotetext{
${ }^{1}$ For example, Becht and Delong (2005: 614) argue that the unusually diffuse ownership of American corporations "is not a long-standing historical tradition." Likewise Cantillo Simon (1998) argues that prior to 1890, American stock markets did not function actively, since corporate ownership was so concentrated in the hands of company founders (Cantillo Simon, 1998). See also Dodd (1938), Hovenkamp (1991) and Coffee (2001). An important exception is Werner (1986).
} 
heavily industrialized states. Entrepreneurs in Massachusetts were pioneers in the textile industry, and developed the first 'integrated' cotton textile mills in the United States in the early nineteenth century (see Ware, 1931). Dozens of enormous textile corporations were eventually founded in the state, and the shares of many of these enterprises were traded on the Boston Stock Exchange, which was then the premier market for American industrial securities (Atack and Rousseau, 1999). In the second half of the nineteenth century, a number of new industries developed in Massachusetts, including chemicals, fabricated metals, and machinery, and entrepreneurs in these industries also made heavy use of the corporate form.

Relative to those of nearly all other states, Massachusetts' corporation law included an unusually strict disclosure requirement which mandated that industrial firms submit 'certificates of condition' to the state government, which listed the names of their directors and stockholders. In this paper I use the certificates filed for the year 1875 to construct a comprehensive dataset of operating industrial corporations in the state, which includes detailed ownership information. I then classify each corporation by industry and match them to data from the state's 1875 manufacturing census, which recorded information on production methods, total numbers of firms and employees, and wages, in different industries. These data present a detailed and comprehensive picture of corporate ownership among industrial firms in the third quarter of the nineteenth century. With the matched data I am able to analyze the variation in incorporation rates as well as the differences in corporate ownership structures across industries. In particular, I can document the extent of the separation of ownership from control among the prominent textile corporations in the state, and compare them to corporations operating in other industries.

The analysis proceeds in three steps. First, I study the adoption of the corporate form across industries. The data reveal substantial variation in incorporation rates, ranging from a high of more than 60 percent among producers of chemicals and of glass, to zero among producers of carriages and wagons. Perhaps unsurprisingly, an analysis of the determinants of 
incorporation rates reveals that they were higher among industries where average firm size, measured by either capital or total employees, was large. However, conditional on firm size, industries that made greater use of steam power and unskilled labor, and industries in which a relatively large proportion of firms' capital was accounted for by fixed assets, were incorporated at higher rates. This is consistent with the notion that the corporate form found heaviest use among those industries in which production was undertaken within factories, rather than artisanal shops. ${ }^{2}$ The data suggest that the corporation was used not only to achieve greater scale, but also to adopt mechanized, factory-based production methods.

In the second step I analyze the ownership of the corporations, and calculate a variety of statistics comparable to those commonly used in the analysis of modern corporate governance. The data indicate that the degree of ownership dispersion in general and managerial ownership in particular varied widely across industries. The great textile corporations, whose shares were traded on the Boston Stock Exchange, were 'widely held' at even higher rates than those of modern American publicly traded corporations. ${ }^{3}$ The degree of the separation of ownership from control among those firms was comparable to large modern publicly traded firms, and Berle and Means (1932) would have characterized nearly all of them as subject to "management control." The ownership structures of those firms certainly contradict any simplistic narrative of the evolution of American corporate ownership in which the separation of ownership from control suddenly occurs at the turn of the twentieth century.

However, the data also indicate that the great textile mills were rather atypical of the state's industrial corporations: they were larger, had greater numbers of shareholders, and lower degrees of managerial ownership. Entrepreneurs were apparently able to use the flexibility of Massachusetts' corporation law to configure their enterprises in a variety of ways,

2 On the distinction between the two, see Katz and Margo (2013) and the references cited therein. On the significance of steam power for productivity, see Atack, Bateman and Margo (2008).

${ }^{3}$ La Porta et al (1999) document that 80 percent of their sample of large modern American public companies are widely held in the sense that they do not have an owner holding 20 percent or more of their stock. In contrast, 98 percent of the manufacturing corporations traded on the Boston Stock Exchange were widely held by that definition. 
according to their needs and circumstances. Most corporations had relatively few shareholders and high levels of managerial ownership, but the degree of ownership concentration observed across industries, and also among firms within particular industries, varied significantly.

Finally I analyze the determinants of ownership concentration and managerial ownership. Unsurprisingly, larger firms were more widely held. But the results indicate that, conditional on firm size, corporations that made greater use of steam power and unskilled labor had more concentrated ownership. That is, relative to corporations of similar sizes in industries that relied more on skilled labor and less on steam power, those in industries that organized production within factories, rather than large artisanal shops, had fewer shareholders, and a greater proportion of the shares were held by the directors. This is consistent with the notion that incorporators and investors responded to the challenges posed by the complex role performed by managers in those firms by ensuring that there was adequate ownership incentives to monitor and supervise management.

This paper contributes to three interrelated lines of research. First, it complements the large and growing literature on the development of manufacturing in New England. ${ }^{4}$ Much of this work has focused narrowly on textiles, and the very large corporations that were formed within that industry (for example, McGouldrick, 1968). This paper complements that work by presenting an account of how the corporate form was utilized within manufacturing. The data reveal that in the third quarter of the nineteenth century, the corporation had proliferated well beyond textiles into a broad range of industries. And across those industries, somewhat different "styles" of ownership were adopted.

Second, the paper contributes to a literature that documents the history of corporate ownership, both in the United States and elsewhere. ${ }^{5}$ This paper complements that literature by

\footnotetext{
4 See, for example, Temin, ed (2000) and Handlin and Handlin (1974).

5 Recent work on British corporations, for example, includes Acheson et al (2014), Cheffins et al (2013), Freeman Pearson and Taylor (2013), and Hannah (2007). Work on the historical ownership of American corporations includes Bodenhorn (2012, 2013), Davis (1958), Hilt and Valentine (2012), Majewski (2006) and Wright (1999).
} 
presenting comprehensive statistics on the ownership of nineteenth century industrial corporations, prior to the rise of 'big business.'

Finally, the paper also contributes to the literature on the adaptability of the corporate form to the needs of small- and medium-sized enterprises (SMEs). Recent contributions to this literature have argued that the corporation laws of American states were quite rigid and regulated governance institutions in ways that were unattractive to SMEs, and that innovations in the menu of organizational forms available to American firms in the later twentieth century, such as the Limited Liability Company (LLC), created alternatives that were vastly superior to the corporation for the needs of SMEs (Guinnane et al, 2007). The results of this paper suggest that there was sufficient flexibility in the corporation law of Massachusetts for entrepreneurs to adapt the corporate form into a wide range of enterprises.

\section{The Massachusetts Legislature and Corporation Law, 1790-1850}

As in most American states, during the first half of the nineteenth century the corporate form was not freely available to entrepreneurs in Massachusetts. Instead, incorporation was only possible if the state legislature passed a law granting a charter to a business. These 'special act charters' were probably not accessible to entrepreneurs who lacked a fair measure of legal sophistication and financial resources. Nonetheless, over the first half of the nineteenth century, Massachusetts granted charters to nearly 550 manufacturing firms. The terms of these charters were initially restrictive in some respects, but they quickly became quite liberal, particularly with regard to the internal governance of the firms they created. This flexibility was unusual, relative to the terms of other states' corporation laws, and may have contributed to the heavy use of the corporate form in Massachusetts.

Beginning in the Early National period, the state government actively used the law to promote economic development, offering public support to private enterprises that would 
furnish transportation infrastructure or develop the capacity for manufacturing (see Handlin and Handlin, 1974). When entrepreneurs sought charters to incorporate manufacturing businesses, they were generally accommodated. As the state industrialized and new companies proliferated, demand for corporate charters grew rapidly, and the state showed a clear willingness to meet that demand. In the first half of the nineteenth century, Massachusetts granted the highest number of corporate charters of all the American states and territories. Figure 1 presents the charters granted by the state in a comparative perspective. By 1850 Massachusetts had granted more than twice the number of corporate charters relative to its population than the national average.

Especially in the period before 1830, however, these charters often did not contain all the terms sought by entrepreneurs. For example, the petition for the Boston Manufacturing Corporation, the firm that would become the first to create an integrated cotton mill, sought banking powers for their enterprise, which were refused (McGouldrick, 1968). The success of that firm and the other Waltham-Lowell mills that followed under the terms of the charters they were granted demonstrated that banking powers were unnecessary. Yet those firms' charters lacked another important power that was routinely granted to manufacturing incorporations in other states: limited liability for the shareholders. The state refused to grant limited liability to any manufacturing corporation in the 1810s and 1820s. All charters granted to such enterprises explicitly made shareholders subject to an 1809 statute, which made them personally liable for their firms' debts. ${ }^{6}$ When it was later objected that shareholders could circumvent this provision by selling their shares to "men of straw," the legislature strengthened its requirement of individual liability by passing legislation that made shareholders liable for any debts incurred

\footnotetext{
${ }^{6}$ This general regulating act for manufacturing companies to some extent standardized many of the terms in subsequent charters, and helped reduce the scope for special privileges to be granted in particular charters. Massachusetts Laws, 1809, ch. 65. The special privileges granted to some very early Massachusetts manufacturing corporations, ranging from lottery tickets to grants of land, are described in Davis (1917).
} 
while they were shareholders, even if they subsequently sold their shares. ${ }^{7}$ Yet in spite of this restriction, manufacturing enterprises sought to incorporate in Massachusetts at very high rates; from 1800-1809, 15 charters were granted to manufacturing enterprises, and from 1810-1819, 133 were granted. In the 1820s, another 146 were granted. ${ }^{8}$

The burden of unlimited liability for shareholders ultimately came to be perceived by many to be limiting economic development. In 1829, a year of high numbers of business failures, the personal liability of many households owning corporate stock led to "wide spreading and irretrievable ruin to individuals." ${ }^{\prime 9}$ Ultimately the governor, Levi Lincoln, took up the cause and despite the vigorous opposition of some influential merchants, a new law granting limited liability to manufacturing enterprises was passed in $1830 .{ }^{10}$ This law, a "general regulating act" that dictated virtually all of the terms of subsequent manufacturing charters, stated that the shareholders of these enterprises would have unlimited liability for debts until their capital subscriptions were fully paid-in, at which point their liability would be limited to the amount of their shares. The act included various other safeguards for the creditors of corporations, for example limiting total indebtedness, and prohibiting the payment of dividends from the capital stock or loans to stockholders.

The 1830 act did not, however, include any terms relative to the governance of the corporations subsequently created, other that imposing the requirement that each corporation have a president, a clerk, a treasurer, and at least three directors. The voting rights of the shareholders, and their method for choosing these officers, were left to the corporations themselves to decide. The silence of the law on these issues was quite unusual; most states' early corporation laws strictly regulated director elections and shareholder voting rights (Hilt, 2013). All subsequent manufacturing charters were quite brief, stating only the name of the firm, the nature of its operations, and the size of its capital stock, and then simply indicating that the firm

${ }^{7}$ Massachusetts Laws,1822, ch. 38.

8 Massachusetts Senate Documents, 1836, no. 90.

${ }^{9}$ Governor's message, J anuary 1830, in Massachusetts Resolves, 1830.

10 Massachusetts Laws, 1830, ch. 53. 
was subject to the 1830 act. In the 20 years between 1830 and 1850, Massachusetts granted more than 400 charters to manufacturing firms. ${ }^{11}$

Finally, in 1851 Massachusetts took the important step of passing a general incorporation act for manufacturing enterprises. ${ }^{12}$ Rather that applying to the legislature for a charter, the act provided that any three people could form a corporation, in virtually any manufacturing or mining industry, by simply filing the certificates required in the act with the Secretary of the Commonwealth and with their county. ${ }^{13}$ Following the precedent of the 1830 general regulating act, the 1851 general incorporation act was mostly silent regarding the internal governance of the corporations, beyond requiring that the firms have a president and a treasurer-the act did not even specify a minimum or maximum number of directors. The act required that corporations created through its terms have a minimum of $\$ 5,000$ in capital, and also imposed a maximum of $\$ 200,000$, which was far smaller than the capital of many chartered corporations. The legislature thus intended the statute to serve as an alternative route to incorporation for small firms, while still requiring large firms to seek charters from the legislature. In 1855, the maximum capital permitted for corporations formed under the general act was raised to $\$ 500,000$, but the legislature continued to retain control over access to the corporate form for extremely large enterprises. ${ }^{14}$

The 1851 general act imposed one significant burden on the corporations created through its terms that chartered corporations were not subject to. And that was an annual report, known as a certificate of condition, which stated the names of the officers and shareholders, and provided other basic information. ${ }^{15}$ But in 1870 the state formally imposed a requirement that a more detailed certificate of condition be submitted annually by all industrial

\footnotetext{
${ }^{11}$ Author's calculations from the charters themselves, obtained from Massachusetts Laws, 1830-1850.

${ }^{12}$ Massachusetts Laws, 1851, ch. 133.

${ }^{13}$ Massachusetts was relatively late to adopt a general incorporation act; see Hilt (2013) for a comprehensive tabulation of general incorporation acts for manufacturing firms.

14 Massachusetts Laws, 1855, ch. 68.

15 Unfortunately, the certificates of condition submitted prior to 1870 do not survive.
} 
corporations in the state, whether they were chartered or incorporated through the general act. These certificates of condition form the basis for the data analyzed in this paper.

\section{The Adoption of the Corporate Form in Massachusetts}

The corporate form was utilized with great frequency, but many multi-owner firms of course remained unincorporated, effectively choosing to remain partnerships. The privileges of incorporation should have been most attractive to firms seeking to raise relatively large amounts of capital from investors. For example, the transferability of shares, the governance structure of a board of directors to whom control over day-to-day management would be delegated, and the limitation of personal liability for shareholders would all seem to be well suited to the needs of passive, outside investors. For a firm with a small number of owners, who were perhaps from the same family, the formalities of an annual meeting and director elections, and the requirement of detailed annual disclosures, probably represented a substantial nuisance. On the other hand, the corporation laws of Massachusetts were relatively flexible, and effectively permitted incorporators to configure their enterprises' voting rights and decision making procedures as they wished. Did small firms, or firms with small numbers of owners, actually incorporate?

One way to address these questions is to examine the industries in which firms chose to incorporate at high rates, and compare them to industries in which incorporation was uncommon. Massachusetts' manufacturing censuses reported detailed information on the total numbers of establishments, their capital, and their employees, by industry. These records can be compared to the filings of manufacturing corporations, whose certificates of condition stated their capital and other information. The certificates unfortunately do not specify the industry of the corporation or its products or revenue. However, the corporate names (eg., "Bay State Faucet and Valve Company") often provide a relatively clear indication of the firm's industry. 
For those with names that do not provide identifying industrial information (eg., "Paul Whitin Manufacturing Company") contemporary business directories were used to classify most corporations into the categories of the state census. ${ }^{16}$ The earliest year for which totally comprehensive corporation records are available, and a manufacturing census is available, is 1875. ${ }^{17}$ In that year, the manufacturing census listed more than 10,000 manufacturing establishments in Massachusetts, and the certificates of condition of 601 corporations could be classified into the industrial categories of the census. ${ }^{18}$

The resulting data are presented in Table $1 .{ }^{19}$ The data in the table show quite clearly that incorporation rates differed significantly across industries. Several of the state's largest industries (measured by the number of establishments), such as boots and shoes, clothing, food preparations, and printing and publishing, had very few incorporated firms at all, and vanishingly low incorporation rates. At the other end of the spectrum, there were smaller industries with relatively small numbers of establishments, such as chemicals, glass, jute baggings, and textile printing ("print works"), where the corporate form was quite dominant. The various categories within the textile industry, as expected, had large numbers of corporations and relatively high incorporation rates. But there were also relatively lange

\footnotetext{
${ }^{16}$ In particular, the Massachusetts Register and Business Directory (1878) and the New England Business Directory and Gazetteer (1877) were consulted, along with directories of individual towns. The industries of 11 of corporations could not be identified and were excluded from the analysis. 17 The collection and analysis of the data for the 1875 census was overseen by the chief of the Massachusetts Bureau of Statistics of Labor, Carroll D. Wright, who would later become the U.S. Commissioner of Labor and oversee the 1890 Federal Census. The 1875 Massachusetts Census was designed and implemented using relatively sophisticated methods, and represented a substantial improvement over earlier state censuses. See Wright (1877).

18 The state census did not require a minimum for revenues or size for establishments to be included in the census (Wright, 1877: 103). However, excluded from these data are around 11,000 firms engaged in "occupations," rather than manufacturing. These occupations included blacksmithing, coopering, butchering, painting, sewing machine repairing, fish curing, butchering, cobbling, tinsmithing, roofing, plumbing, and related tasks. These firms had been classified as engaged in manufacturing in earlier state censuses.

19 The average capital of all establishments, column (2) in the table, is calculated by dividing total capital in the industry by the number of establishments. There is not sufficient data to calculate median capital from the census data. The table excludes industry categories with very few firms, and industry categories where the census reports did not present data on firm characteristics.
} 
numbers of incorporated firms producing machinery, metallic goods, paper, and brick and stone.

The data in the table also seem consistent with the notion that incorporation rates were higher in industries with higher average capital per firm. The industries with the smallest average firm capital, such as tobacco, lumber, vessels, and carriages and wagons, all had incorporation rates of 2 percent or less, whereas those with the highest firm capital, such as cotton goods, textile printing, linen, and "other textiles," all had incorporation rates of more than 40 percent. The data in Table 1 also indicate that in all but one industry, the average capital of corporations was larger than the average capital of all establishments, sometimes by as much as a factor of ten. In at least a few cases, it seems very likely that the corporations were effectively operating in a different industry, even though according to the rough classification system of the census they were grouped into the same category.

How consistent is the relationship between average firm size and incorporation rates at the industry level? An analysis of the relationship between firm size and incorporation rates across industries is presented in Figure 2. The scatterplot in the figure indicates that industries with higher levels of capital per firm (in logs) indeed had higher incorporation rates. The regression line included in the figure illustrates the strong tendency towards higher incorporation rates among firms in industries with higher average capital. However, the residuals of many industries are also high, and in particular, there are several industries with relatively high incorporation rates and relatively low levels of average capital. The lower panel illustrates the same pattern, but using the log of total employees, rather than capital, as a measure of firm size.

The census recorded detailed data on certain elements of manufacturing firms' capital, workforce, and operations. These data, which are summarized in Table 2, provide some insight into the production methods utilized by firms in different industries. For example, some industries appear to have been dominated by artisanal shops, with relatively small numbers of 
workers and little fixed capital. Producers of tobacco products, scientific instruments, and food preparations on average had fewer than six employees, and less than $\$ 10,000$ in capital. Firms in each of these industries also made relatively little use of steam power, with around 0.10 steam engines per establishment or less. In contrast, producers of cotton goods, linen, and print works typically had well over 200 employees and $\$ 200,000$ or more in capital, and in these industries there were 0.8 steam engines per establishment. Establishments in these industries are best characterized as factories.

Likewise the workforce of some industries consisted of a relatively large proportion of skilled labor, whereas others relied heavily on unskilled labor. The table presents proxies for the share of skilled labor, based on wages and the gender composition of the labor force. A higher wage is consistent with a greater level of skill; the fraction of the labor force that was female is an indicator for the proportion that was unskilled. The table presents wages for all workers, which reflects the mix of skilled and unskilled labor (in the form of women and children) and also the wage for adult male workers only. The industries with the highest levels of wages were musical instruments and clocks and watches, whose adult male workers earned $\$ 876$ and $\$ 882$ per year, respectively. The lowest wages of adult males were in jute baggings ( $\$ 307)$ and linen (\$390), and in these industries female workers represented more than 50 percent of total employees.

We can gain some insight into the purposes for which the corporate form was utilized by analyzing how incorporation rates varied with these industry characteristics. In addition to achieving a greater scale, incorporation facilitated the creation of firms that utilized particular kinds of assets or production processes, and the variation in incorporation rates across industries reflected these patterns. Table 3 presents regressions of industry-level incorporation rates on industry characteristics. Panel A presents univariate regressions, and since many of these characteristics may be correlated with firm scale, in Panel B the regressions are repeated with a measure of scale included-the log of the number of employees per establishment. 
The estimates in Panel A indicate clearly that incorporation rates were higher in industries in which production took place primarily within factories, rather than artisanal shops. The capital-output ratio, the use of steam power, and the use of unskilled labor (reflected in both lower average wages and a higher percentage of female labor, although the latter estimate is not statistically significant) were all substantially higher among industries with higher incorporation rates. The incorporation rate also varied with the composition of firms' capital. Column (3) presents regressions of the percentage of firms' assets represented by 'fixed assets' - buildings and machinery - rather than stock on hand. This measure was also positively correlated with incorporation rates, which likely reflects the fact that the capital of incorporated firms was used to finance fixed investments. ${ }^{20}$

Finally, Column (7) regresses the growth rate of industry output in Massachusetts between the 1865 and 1875 censuses on incorporation rates. If the corporate form facilitated investments in rapidly growing, new or innovative industries, then one would expect that this measure would be positively correlated with incorporation rates. However, the estimated correlation is negative, and even significant at the 10 percent level. This is likely due to the negative correlation between industry growth rates and average firm size - industries with larger firms grew more slowly. ${ }^{21}$

In Panel B of Table 3, the same regressions are estimated, but with log total employees included as a measure of scale. That is, in these regressions the relationship between industry characteristics and incorporation rates are analyzed, conditional on average firm size. Some of the estimated relationships change substantially, implying that the correlations in Panel A were

\footnotetext{
20 In contrast, working capital ('stock on hand') was likely financed by commercial credit. All else equal, borrowing terms for unincorporated firms, whose owners faced unlimited liability, may have been more favorable than those faced by incorporated firms, and this may have contributed to the lower incorporation rates among firms in which stock on hand represented a substantial portion of total assets. ${ }^{21}$ The correlation between the industry growth rate and log total employees was -0.36 . It should also be noted that over the 1865-75 period many industries in Massachusetts contracted significantly, and this contraction may have been related to the end of the Civil War. In addition to the arms and ammunition industry, which contracted by more than 70 percent, the oils and illuminating fluids, glass, and woolen goods industries, all of which had relatively high incorporation rates, saw substantial contractions in their output.
} 
simply due to the greater scale in industries that had higher incorporation rates. In particular, the estimated correlations with the capital-output ratio (Column (1)), the percentage of the labor force that was female (Column (4)), the log wage for all employees (Column (5)), and the growth rate of industry output following 1865 (Column (7)) all show substantial decreases in absolute magnitude and statistical significance. Evidently these relationships were driven by scale. Interestingly, the log average wage paid to adult male employees - which should reflect the degree of skill among those workers, rather than the overall mix of skilled and unskilled labor continues to indicate a strong negative relationship, although the magnitude of the estimate is diminished. Likewise the estimated effects of the use of steam power and the fraction of firm assets represented by fixed capital, both of which were likely correlated with factory production, were robustly correlated with incorporation rates, even conditional on firm scale.

Unfortunately it is impossible to infer from these data whether access to the corporate form enabled firms to form that could not otherwise have been created, or if it enabled firms to achieve a greater scale or adopt different production methods than would have been possible otherwise. It is worth noting that if the corporate form enabled firms to increase their scale or adopt steam power, relative to what was attainable as a partnership, then these results imply that the corporate form increased productivity. Using data from the federal census, Atack, Bateman and Margo (2008) find strong productivity gains associated with the adoption of steam power, and that these gains were increasing in firm size.

But overall these results indicate that corporations were formed in industries in which establishments resembled factories more than artisanal shops. Even conditional on average firm size, industries with high incorporation rates were more likely to utilize steam power, and relied on less skilled male workers, relative to their peers. In what follows, I analyze the ownership of corporations, and how their governance may have responded to these industry characteristics. 


\section{Ownership and Governance of Massachusetts' Corporations}

Concentrated corporate ownership imposes costs, and also presents some benefits. The most obvious cost is that the wealth of investors holding large blocks of stock will be illiquid and poorly diversified. In cases where a shareholder holds a controlling stake, an additional cost may arise, namely that the controlling shareholder may engage in 'tunneling' or other actions that benefit himself at the cost of the other owners, and those other owners may have little recourse. On the other hand, concentrated ownership creates incentives for investors to monitor the management of the firm. In the nineteenth century many corporate directors likely participated directly in management (they were the managers), implying that large stakes held by the board would create strong ownership incentives for diligent effort. One of the main arguments of Berle and Means (1932) is that when there are no large blockholders, control falls into the hands of management, who become unaccountable to the shareholders, except in rare circumstances.

The historical record indicates that among the very large textile corporations in the state, there was an absence of substantial owners who would have had strong incentives to monitor management, and this appears to have been a source of some concern. There is a long tradition of sophisticated merchants expressing skepticism that the managers of early corporations would be capable of performing as well as those who operated on "an individual basis." For example, Henry Lee, a Boston merchant, complained in his correspondence that many major textile corporations were "in danger of being ruined by extreme salaries and high wages in all the departments," a problem he attributed to weak performance incentives for managers (Porter, 1937: 125). But the most clear and direct evidence of such managerial opportunism is found in the early 1860s, when an activist investor named J .C. Ayer initiated a campaign to reform the governance institutions of the major textile corporations. He produced a pamphlet, On the Usages and Abuses in the Management of Our Manufacturing Corporations (1863) that argued 
that opportunism by directors was rampant: they engaged in self-dealing in their transactions with firms to whom the purchase of raw materials or the sale of finished products were delegated, and paid excessive fees; they hired their relatives for important supervisory positions; they drew excessively high salaries; and they concealed the effects of these practices from the shareholders. Ayer specifically argued that "relations of owners and managers" had changed since the founding of the companies, since the existing owners were completely passive, and bought their shares "in the hope that somebody interested in it can and will take care of it." He also argued that the directors perpetuated their control over their firms by soliciting proxy votes from the shareholders through duplicitous means, and, where necessary, by holding the annual meetings of companies with many shareholders in common simultaneously, thereby preventing the larger shareholders from participating in more than one.

Although it is impossible to verify many of Ayer's claims, it is possible to discern the level of shareholder participation in annual meetings for at least a handful of companies, and thereby assess whether or not the scope for managerial opportunism was as broad as Ayer claimed. And indeed it does appear to be the case that stockholders participated in annual meetings only infrequently. ${ }^{22}$ The Massachusetts legislature responded to the complaints of Ayer and other stockholders by enacting a statute in 1865 intended to limit the power of directors to utilize proxy votes to perpetuate their control. ${ }^{23}$ In particular, the statute limited the number of proxy votes that a sitting director could exercise to 20 , a very small fraction of the total of around 1,000 shares that were typically outstanding.

\subsection{0wnership structures of manufacturing companies}

Whether or not these problems were representative of those faced by investors in early manufacturing corporations generally depends at least in part on how unusual the ownership

22 For example, between 1850 and 1875, the number of stockholders in the Pepperell Manufacturing Company grew from 117 to 321 . At the annual meetings during that period, the number of stockholders present generally ranged from 10 to 25 (Knowlton 1948: 16). See also McGouldrick (1968).

23 Massachusetts Laws, 1865, ch. 236. 
structures of the great textile corporations were, relative to other firms. Panel A of Table 4 presents data on the degree of ownership concentration among all manufacturing corporations. The average manufacturing corporation had around \$210,000 in paid-in capital, and 47 shareholders. It had a relatively small board consisting of four directors, who owned around 45 percent of the shares. Its ownership was relatively concentrated the standards of modern public companies, with the largest investor holding 28 percent of the shares. By the definition of La Porta, et al (1999), only about 42 percent of Massachusetts' corporations were 'widely held,' in the sense of not having a 20 percent owner. For the average firm, the complaints of Ayer seem unlikely to have been relevant.

Panel B of the table presents the same statistics for the 31 manufacturing corporations in the sample whose shares were traded on the Boston Stock Exchange. ${ }^{24}$ Those firms included most of the great Waltham-Lowell textile mills, as well as a few other major industrial firms from other regions in the state. The data reveal that the Boston Stock Exchange firms were quite unusual. Their capital was more than fourfold greater than average, and their numbers of shareholders were fivefold greater. Ownership by management was less than one fourth that of the average corporation, as was the size of the largest stake held. These were huge corporations with an extraordinary degree of diffusion in their ownership. The problems faced by the shareholders of these firms were likely unique.

A more detailed portrait of the structure of ownership of manufacturing corporations is presented in Table 5, which shows averages for each industry group where there was more than one operating corporation. The data in the table indicate that in nearly every industry, managerial ownership was on average quite significant, and typically the largest blockholder owned more than 20 percent of the shares. Concentrated ownership was the norm, and the managers' own stakes were likely sufficiently large so that they would at least partly internalize

24 Martin's Boston Stock Market indicates that in 1875, the stocks of around 44 New England manufacturing companies were traded regularly on the Boston Stock Exchange. Among those 44, at least 11 were located in other states. See Atack and Rousseau (1999) on the performance of Boston Stock Exchange traded shares during this period. 
the costs associated with shirking or taking other actions harmful to the performance of the firm. On the other hand, their stakes were often so large that they held majority control and could not be removed from their positions by the other shareholders. This suggests that oppression of minority shareholders by dominant owners was likely to have been a problem among a substantial portion of the corporations..$^{25}$

What explains the variation in ownership structures across industries? Why did some firms have much larger managerial ownership and smaller numbers of outside shareholders than others? The data in Table 5 suggest that scale played a role: in the industries with the largest average capital, the degree of ownership concentration appears to be lower. This was likely driven at least in part by the constraints of raising large sums of money-it was probably necessary in the case of very large firms for a group of founding investors to seek investments from large numbers of outsiders.

The relationship between average firm scale and ownership across industries is explored more systematically in Figure 3. The scatter plots in the figure clearly indicate that the number of shareholders was increasing, and the degree of managerial ownership was decreasing, in the average scale of the firm. However, scale was not the only driving force behind the variation in ownership concentration. Across industries and firms, ownership was likely more concentrated where the resulting benefits were greater. The next section analyzes the variation in ownership concentration, and investigates the circumstances in which there may have been greater benefits to more concentrated ownership.

\subsection{Ownership structures and production methods}

The corporate form was adapted into a broad range of industries. Incorporators' endogenous choice of governance institutions in response to the particular circumstances of their firms renders any analysis of the relationship between governance institutions and firm

${ }^{25}$ Hilt (2008) argues that early corporate governance institutions were often focused on addressing this problem. 
performance empirically problematic. But those choices of governance institutions, and how they responded to industry characteristics and production methods can be analyzed empirically, particularly if these industry characteristics can be taken as exogenous for individual incorporators within that industry.

In what follows, I analyze how the degree of ownership concentration, which is likely to be correlated with owners' incentives to monitor management, varied with the production methods used across industries. The corporate form was adapted into industries dominated by establishments resembling artisanal shops, and, more typically, industries dominated by factories. Factories made greater use of steam power and unskilled labor, and their production processes likely created a greater division of labor and specialization of tasks among employees (see the discussion in Katz and Margo, 2013). Among these firms, managers likely performed a complex supervisory role that was critically important to the success of the firm. Although the organizational structure of most manufacturing corporations in 1875 was likely rather simple, some of the larger and more complex firms may have begun to develop new managerial systems and organizational structures (Chandler, 1977). The complexity and importance of the role of managers within these firms, and the potential difficulties outsiders may have faced in monitoring and evaluating their performance, likely presented a challenge for their governance. Concentrated ownership may have been a solution.

From the certificates of condition, we cannot observe the production process or managerial structure of the corporations. However, the industry averages available from the census, which reflect the typical production methods used among all firms, can be used as a proxy for the firms' own process. To the extent that they reflect the available choices of production methods given the state of technology and knowledge of management techniques, these industry averages can be taken as exogenous determinants of the governance institutions of individual corporations within each industry. In order to analyze this relationship, I estimate the following model: 


$$
y_{i j c}=\alpha+\delta_{c}+\operatorname{rprod}_{j}+\theta \log k_{i}+X \beta+\varepsilon_{i}
$$

where $y_{i j c}$ is the governance measure of interest for firm i in industry $\mathrm{j}$ in county c, $\delta_{c}$ is a county fixed effect, $\operatorname{prod}_{j}$ is the average production method (such as the rate of use of steam power) in industry $\mathrm{j}, \log k_{i}$ is the $\log$ level of capital of firm $\mathrm{i}$, and $X$ is a vector of other characteristics observed at the firm level. Thus the model estimates the relationship between industry-average production methods and the governance of individual firms, conditional on firm scale. Controls for geographical locations, in the form of county fixed effects, are included in order to address the possibility that different production techniques (again, such as the use of steam power) may have shifted the location of production into places that may have independently influenced firms' governance structures. In order to address potential problems associated with the use of industry-averages for the production method variables used in the regression, the standard errors will be adjusted for clustering by industry. The governance characteristics used as dependent variables in these regressions are the log number of shareholders, the fraction of the firm owned by the directors, the size of the board, and the size of the largest stake held.

Table 6 presents the results for specifications using steam power, the log annual wage paid to adult male employees, and the fraction of the workforce that was female- the first an indication of factory production, the second an indication of a greater degree of skilled labor, less consistent with factory production, and the third a measure of the use of unskilled labor, consistent with factory production. The results of all specifications are clear and broadly consistent. The use of factory production methods, conditional on firm scale, was associated with more concentrated ownership and stronger governance by shareholders. In particular, the upper panel of Table 6 indicates that in industries that relied more heavily on steam power, the corporations had fewer shareholders, were owned to a larger extent by their directors, had smaller board sizes, and the size of the largest stake held in their equity was greater. ${ }^{26}$ In

${ }^{26}$ Larger boards of directors have been found to hamper performance across a variety of measures among modern corporations; see Yermack (1996) and the references cited therein. 
contrast, corporations in industries where the wages paid to adult male workers were higher, which likely utilized more skilled labor in their production, had larger numbers of shareholders, lower ownership by directors, larger boards, and smaller maximum ownership stakes. The estimates for the share of the workforce that was female, although smaller and less statistically precise, are of the same sign as those for the use of steam power.

One potential source of concern with these results could be that an omitted variable, firm age, may be partly responsible for the observed correlations. If newer corporations tended to be formed in industries that utilized factory production methods, and newer corporations also had more concentrated ownership structures, as their founders had not yet sold off parts of their stakes (and the shares generally had less time to diffuse among investors), then the observed correlations between production methods and firm governance could be driven by firm age. In order to address this possibility, the date of incorporation of each firm was obtained from the Massachusetts Tax Commissioner's Annual Report, and from it the log age of each firm was calculated.

Table 7 presents the results of regressions of the same specifications as those of Table 6 , but with log firm age included as an additional control. As expected, firm age is positively and strongly correlated with the number of shareholders, although not with other measures of ownership concentration. However, the inclusion of this variable does not substantially change the estimated effects of the production methods of the corporations on their governance. We can conclude that the results are not driven by firm age.

These results are somewhat speculative, and await confirmation in future work using more detailed data in which production methods can be observed for individual firms, rather than at the industry level. Nonetheless, they suggest that one of the ways in which the corporate form was successfully adapted into different industrial contexts was that ownership structures and governance institutions were varied endogenously. In particular, in corporations that operated in industries that relied heavily on factory production using steam power and a high 
proportion of unskilled labor, there was more concentrated ownership relative to corporations of similar sizes in industries that relied more on skilled labor and less on steam power. This is consistent with the notion that incorporators and investors responded to the challenges posed by the complex role performed by managers in those firms by ensuring that there was adequate ownership incentives to monitor and supervise management.

\section{Conclusion and Epilogue}

Over the course of the nineteenth century the corporate form was adopted at high rates by manufacturing firms, particularly in Massachusetts. This paper has analyzed the variation in incorporation rates, and the ways that corporations were owned and configured, across industries in 1875.

One important finding of the paper is that among the large textile corporations of the state-the so-called Waltham-Lowell mills, whose shares were traded on the Boston Stock Exchange - the degree of ownership by the board was extraordinarily low, and there were very few if any large blockholders. The degree of separation of ownership from control among these firms was in fact typical of widely held modern American firms. However, the data presented in the paper indicate that the great textile corporations were quite unusual. Most nineteenthcentury manufacturing corporations were smaller, had fewer owners, and a high degree of ownership by their managers. Some were indeed extremely small; around 10 percent had four shareholders or fewer. And many of these firms adapted the corporate form to their needs by creating extremely small boards of directors; 10 percent had boards of two or fewer people. Most Massachusetts corporations were in fact controlled and operated by the men who owned them.

Unsurprisingly, the corporate form was adopted more frequently among firms in industries where average establishment size was higher. However, conditional on firm size, 
industries that made greater use of steam power and unskilled labor were incorporated at higher rates. This is consistent with the notion that the corporate form found heaviest use among those industries in which production was undertaken within factories, rather than artisanal shops. Evidently the corporation was used not only to achieve greater scale, but also to adopt mechanized, factory-based production methods.

The results also indicate that, conditional on firm size, corporations operating in industries that made greater use of steam power and unskilled labor had more concentrated ownership. That is, relative to corporations of similar sizes, those in industries that organized production within factories, rather than artisanal shops, had fewer shareholders, and a greater proportion of the shares were held by the directors. This is consistent with the notion that incorporators and investors responded to the challenges posed by the complex role performed by managers in those firms by ensuring that there was adequate ownership incentives to monitor and supervise management.

What happened after 1875? In the 1890s, several states, beginning with NewJ ersey, substantially liberalized their corporation laws, permitting businesses located in other states to incorporate within their borders, eliminating many restrictions on capital contributions, and enabling the formation of holding companies (see Larcom, 1937 and Grandy, 1989). For a brief period, Massachusetts' corporation laws, with their detailed annual disclosure requirements and strict limitations on corporate powers, were among the most conservative in the United States. ${ }^{27}$ Ultimately in 1903, Massachusetts substantially liberalized its laws to reflect the "modern view that the State owes no duty to investors to look after the solvency of corporations" (Hall, 1908). With this change, the detailed data on business corporations utilized for this study ceased to be collected.

27 When Theodore Roosevelt became President, his first message to Congress signaled his intention to impose federal corporation laws, but reassure the business community that "supervision of corporations by the National Government need not go so far as is now the case with the supervision exercised over them by so conservative a State as Massachusetts" (Roosevelt, 1901). 
Nevertheless, it is possible to follow the evolution of the use of the business corporation in Massachusetts into the early twentieth century using data generated by the imposition and collection of the federal corporate income tax in 1909. In 1909, there were 3,637 operating manufacturing corporations in the state, with $\$ 1.013$ billion in capital. This was equivalent to 1.08 manufacturing corporations and \$598 in capital per 1,000 persons, relative to a national average of 0.97 manufacturing corporations and \$234 in capital nationally. ${ }^{28}$ Thus Massachusetts remained a prominent center of manufacturing corporations, but it was no longer as unusual in the extent to which the corporate form was utilized as it had been in the mid-nineteenth century. As new industries and new centers of innovation emerged, and as many states revised and liberalized their corporation laws, Massachusetts was eclipsed by other states.

28 Author's calculations from U.S. Treasury (1910) and the Federal Census. It is important to note that these data are not directly comparable to those of Figure 1, which presents the total number of corporations created in all sectors, rather than manufacturing corporations that were actually in operation. 


\section{References}

Acheson, Graeme, Campbell, Gareth, Turner, John D., Vanteeva, Nadia. 2014. “Corporate Ownership and Control in Victorian Britain," QUCEH Working Paper Series, No. 14-01.

Angell, J oseph K., and Samuel Ames. 1832. A Treatise on the Law of Private Corporations Aggregate. Boston: Hilliard, Gray, Little \& Wilkins.

Atack, J eremy. 1985. "Industrial Structure and the Emergence of the Modern Industrial Corporation," Explorations in Economic History, 22, 29-52.

Atack, J eremy, Bateman, Fred, and Robert A. Margo. 2008. "Steam power, establishment size, and labor productivity growth in nineteenth-century American manufacturing," Explorations in Economic History, 45, 185-198.

Atack, J eremy, and Peter Rousseau. 1999. "Business activity and the Boston Stock Market, 183569," Explorations in Economic History, 36, 144-79.

Ayer, J.C. 1863. Some of the Usages and Abuses in the Management of Our Manufacturing Corporations. Lowell: C M Langley \& Co.

Becht, Marco, and J . Bradford Delong. 2005. "Why Has there been so Little Blockholding in America?" in Morck, ed., A History of Corporate Governance Around the World. Chicago: University of Chicago Press.

Bemis, Edward W. 1888. "Cooperation in New England," in Adams, Herbert B., ed., J ohns Hopkins University Studies in Historical and Political Science, sixth series, no. I-II. Baltimore: J ohns Hopkins.

Berle, Adolf, and Gardiner Means. 1932. The Modern Corporation and Private Property. New York: Macmillan.

Bodenhorn, Howard. 2012. "Voting Rights, Share Concentration and Leverage in NineteenthCentury U.S. Banks." NBER Working Paper Series, number 17808.

Bodenhorn, Howard. 2013. “Large Block Shareholders, Institutional Investors, Boards of Directors and Bank Value in the Nineteenth Century, NBER Working Paper Series, number 18955.

Boyle, A. J . 1965. "The Minority Shareholder in the Nineteenth Century: A Study in AngloAmerican Legal History," Modern Law Review, 28(3): 317-29.

Cantillo Simon, Miguel. 1998. "The Rise and Fall of Bank Control in the United States: 18901939," American Economic Review, 88(5), 1077-93.

Cheffins, B. R., Chambers, D. and Koustas, D. K. 2013. “Ownership dispersion and the London Stock Exchange's "two-thirds rule": an empirical test," Business History, 55 (2013), pp. 670-93. 
Clark, Victor S. 1929. History of Manufactures in the United States. New York: The Carnegie Institution.

Coffee, J ohn C. 2001. "The Rise of Dispersed Ownership: The Roles of Law and the State in the Separation of Ownership and Control,"Yale Law J ournal, 111 (1), 1-82.

Dalzell, Robert F. 1987. Enterprising Elite: The Boston Associates and the World they Made. Cambridge: Harvard University Press.

Davis, J oseph S. 1917. Essays in the Earlier History of Corporations. Cambridge: Harvard University Press.

Davis, Lance E. 1958. "Stock Ownership in the Early New England Textile Industry," Business History Review, 32,204-222.

Davis, Lance E. 1960. “The New England Textile Mills and the Capital Markets: A Study of Industrial Borrowing 1840-1860,'J ournal of Economic History, 20, 1-30.

Dodd, Edwin M. 1938. Lectures on the Growth of Corporate Structure in the United States with Special Reference to Governmental Regulation. Cleveland: Cleveland Bar Association.

Dodd, Edwin M. 1954. American Business Corporations Until 1860. Cambridge: Harvard University Press.

Dunlavy, Colleen A. 2004. "From Citizens to Plutocrats: 19th-Century Shareholder Voting Rights and Theories of the Corporation." In Constructing Corporate America: History, Politics, Culture, edited by Kenneth Lipartito and David B. Sicilia. Oxford: Oxford University Press, 66-93.

Evans, George H. 1948. Business Incorporations in the United States, 1800-1943. New York: National Bureau of Economic Research.

Freeman, Mark, Pearson, Robin, and J ames Taylor. 2012. Shareholder Democracies? Corporate Governance in Britain and Ireland Before 1850. Chicago: University of Chicago.

Friedman, Lawrence. 2005. A History of American Law. New York: Simon and Schuster.

Gower, L.C.B. 1956. "Some Contrasts Between British and American Corporation Law," Harvard Law Review, 69(8): 1369-1402.

Grandy, Christopher. 1989. “New J ersey Corporate Chartermongering, 1875-1929,”J ournal of Economic History, 49(3), 677-92.

Guinnane, Timothy W., Harris, Ron, Lamoreaux, Naomi, and J ean-Laurent Rosenthal. 2007. "Putting the Corporation in its Place." Enterprise and Society, 8, 687-729.

Hall, Prescott F. 1908. The Massachusetts Business Corporation Law of 1903. Boston: William J. Nagel. 
Handlin, Oscar and Mary Flug Handlin. 1974.Commonwealth: A Study of the Rule of Government in the American Economy, Massachusetts, 1774-1861. Cambridge: Harvard University Press.

Hannah, Leslie. 2007. "The divorce of ownership from control from 1900: re-calibrating imagined global historical trends," Business History, 49, pp. 404-38.

Henderson, Gerard C. 1918. The Position of Foreign Corporations in American Constitutional Law. Cambridge: Harvard University Press.

Hilt, Eric. 2006. “Incentives in Corporations: Evidence from the American Whaling Industry," J ournal of Law and Economics, 49(1): 197-227.

Hilt, Eric. 2008. 'When did Ownership Separate from Control? Corporate Governance in the Early Nineteenth Century," J ournal of Economic History 68: 645-85.

Hilt, Eric, and J acqueline Valentine. 2012. "Democratic Dividends: Stockholding, Wealth, and Politics in New York, 1791- 1826," J ournal of Economic History 72(2), 332-63.

Hilt, Eric. 2013. “General Incorporation Acts for Manufacturing Firms, 1811-1860." Working paper, Wellesley College.

Hovenkamp, Herbert. 1991. Enterprise and American Law, 1836-1937. Cambridge: Harvard University Press.

Hunt, Bishop Carleton. 1936. The Development of the Business Corporation in England, 18001867. Cambridge, MA: Harvard University Press.

Hurst, J ames W. 1956. Law and the Conditions of Freedom in the Nineteenth-Century United States. Madison: University of Wisconsin Press.

Katz, Lawrence, and Robert Margo. 2013. “Technical Change and the Relative Demand for Skilled Labor: The United States in Historical Perspective." NBER Working Paper Series, number 18752.

Kessler, William C. 1940. "A Statistical Study of the New York General Incorporation Act of 1811," J ournal of Political Economy, 48, pp. 877-882.

Kessler, William C. 1948. "Incorporation in New England: A Statistical Study, 1800-1875," J ournal of Economic History, 8, 43-62.

Knowiton, Evelyn H. 1948. Pepperell's Progress: History of A Cotton Textile Company, 18441945. Cambridge: Harvard University Press.

Lamoreaux, Naomi. 2009. "Scylla or Charybdis? Historical Reflections on Two Basic Problems of Corporate Governance," Business History Review, 83: 9-34.

Lamoreaux, Naomi, and J ean-Laurent Rosenthal. 2006. "Corporate Governance and Minority Shareholders in the United States Before the Great Depression," in Corruption and 
Reform: Lessons from America's Economic History, ed. Glaeser and Goldin. Chicago: University of Chicago Press.

La Porta, Rafael, Lopez-de-Silanes, Florencio, and Andrei Shleifer. 1999. “Corporate Ownership around the World," J ournal of Finance, 54(2), 471-517.

Larcom, Russell C. 1937. The Delaware Corporation. Baltimore: J ohns Hopkins Press.

Leiby, J ames. 1960. Carroll Wright and Labor Reform: The Origin of Labor Statistics. Cambridge: Harvard University Press.

Majewski, J ohn. 1996. "Who Financed the Transportation Revolution? Regional Divergence and Internal Improvements in Antebellum Pennsylvania and Virginia," J ournal of Economic History, 56, 763-788.

Majewski, J ohn. 2006. "Toward a Social History of the Corporation: Shareholding in Pennsylvania, 1800-1840," in Matson, ed., The Economy of Early America: Historical Perspectives and New Directions. Philadelphia: University of Pennsylvania.

Martin, J oseph G. 1886. Martin's Boston Stock Market. Boston: Published by the author.

McGouldrick, Paul F. 1968. New England Textiles in the Nineteenth Century. Cambridge: Harvard University Press.

Morck, Randall, Shleifer, Andrei, and Robert W. Vishy. 1988. "Management Ownership and Market Valuation: An Empirical Analysis,” J ournal of Financial Economics, 20, 293315.

Porter, Kenneth W. 1937. The J ackson and the Lees. Cambridge: Harvard University Press.

Roosevelt, Theodore. 1901. Message of the President of the United States Communicated to the Two Houses of Congress at the Beginning of the First Session of the Fifty-Seventh Congress. Washington: Government Printing Office.

Scranton, Philip. 1983. Proprietary Capitalism: The Textile Manufacture at Philadelphia, 1800-1885. New York: Cambridge University Press.

Seavoy, Ronald E. 1982. The Origins of the American Business Corporation, 1784-1855. Westport, CT: Greenview Press.

Sylla, Richard, and Robert E. Wright. 2013. "Corporation formation in the antebellum United States in comparative context," Business History, 55(4), 653-69.

Temin, Peter. 2000. “The Industrialization of New England, 1830-1880," in Temin, ed. Engines of Enterprise: An Economic History of New England. Cambridge: Harvard University Press.

U.S. Treasury. 1910. Annual Report of the Commissioner of Internal Revenue for the Fiscal Year Ended J une 30 1910. House of Representatives, Document 1045. Washington: Government Printing Office. 
Wallis, J ohn J . 2003. "Market-Augmenting Government? States and Corporations in Nineteenth-Century America," in Market-Augmenting Government, The Institutional Foundations of Prosperity, ed. Omar Azfar \& Charles A Caldwell. Ann Arbor: University of Michigan Press.

Ware, Caroline F. 1931. The Early New England Cotton Manufacture. New York: Houghton Mifflin.

Werner, Walter. 1986. "Corporate Law In Search of Its Future," Columbia Law Review, 81, 1610-1666.

Wright, Carroll D. 1877. A Compendium of the Census of Massachusetts: 1875. Boston: AlbertJ. Wright.

Wright, Robert E. 1999. “Bank Ownership and Lending Patterns in New York and Pennsylvania, 1781-1831," Business History Review, 73, 40-60.

Yermack, David. 1996. "Higher market valuation of companies with a small board of directors," J ournal of Financial Economics, 40(2), 185-211. 


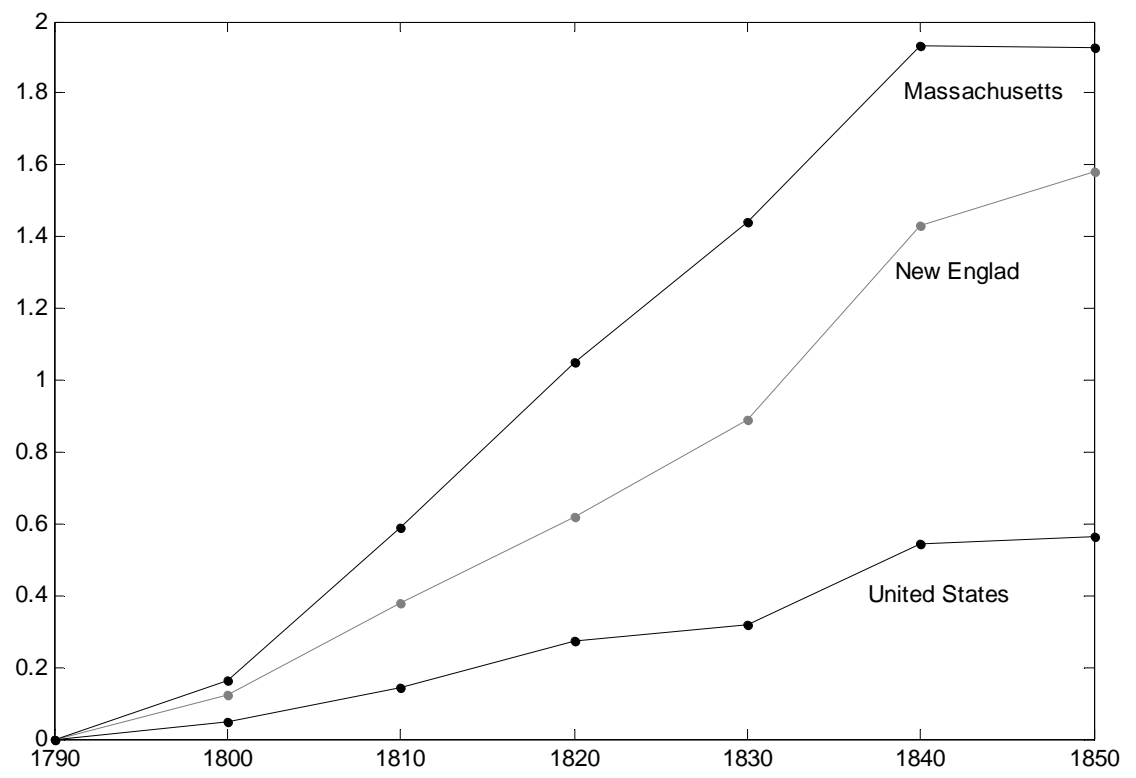

Figure 1: Cumulative Corporate Charters per 1,000 Persons

Sources: Corporate charters from Sylla and Wright (2013); population figures from the decennial federal census. Note: The data do not include corporations created through general acts 

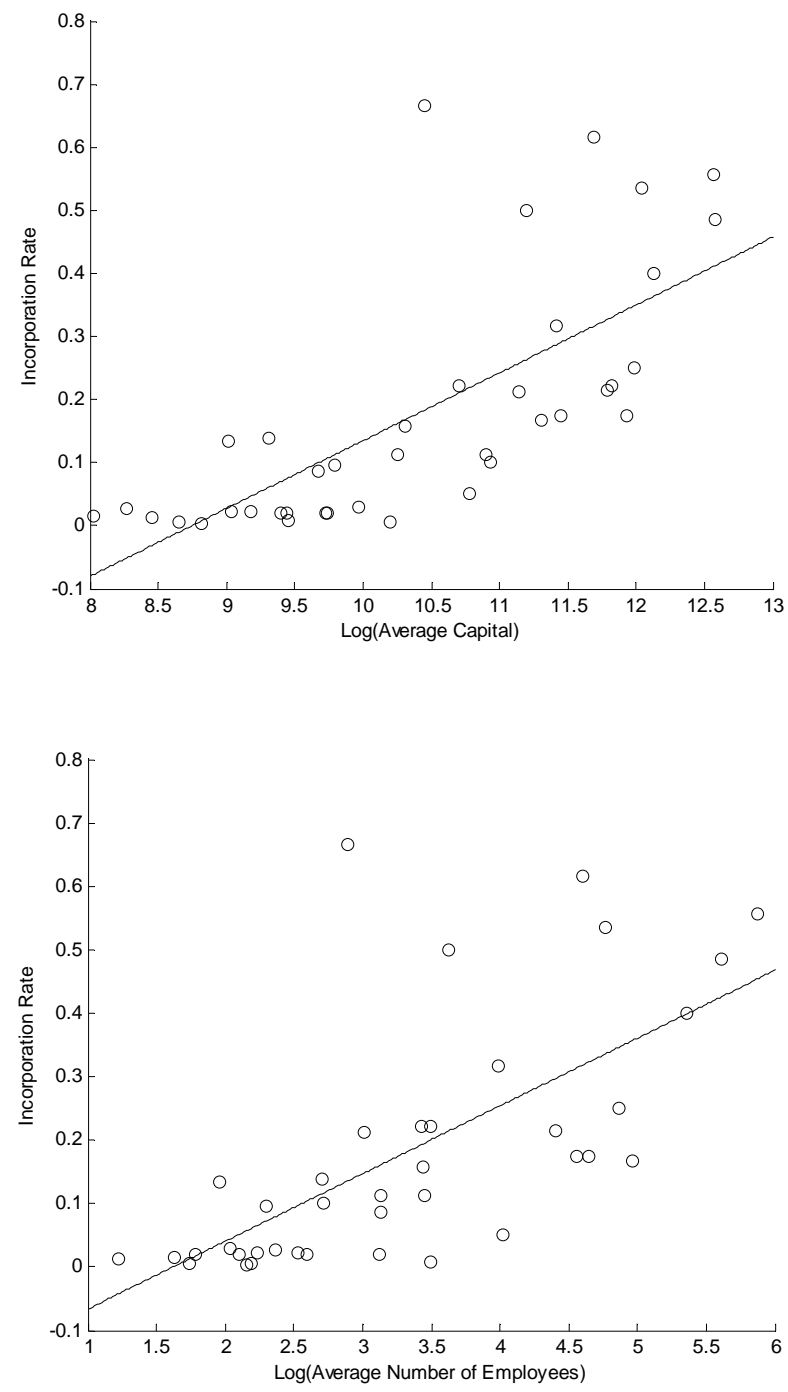

Figure 2: Incorporation Rates and Firm Characteristics by Industry 

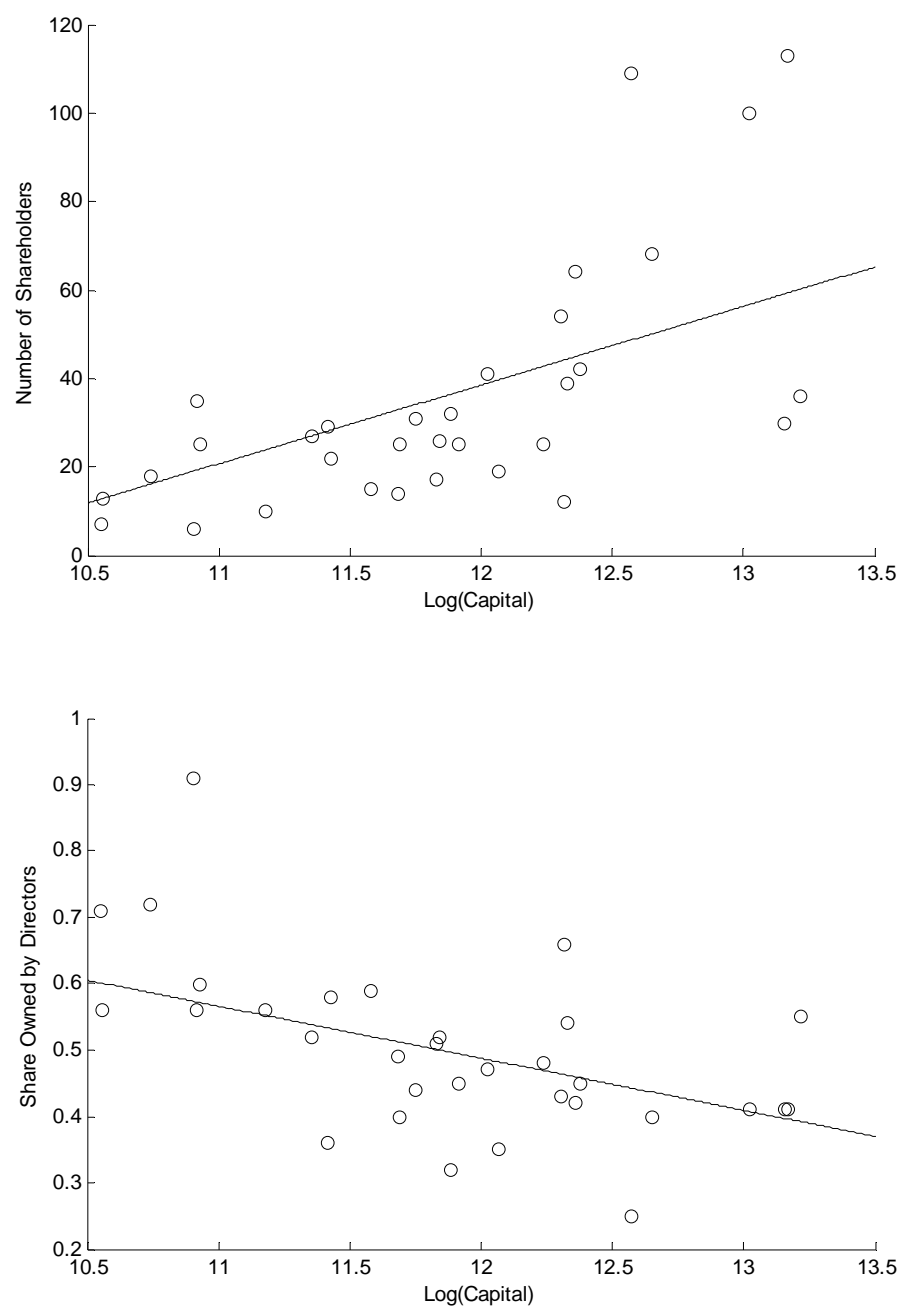

Figure 3: Firm Size and Ownership Structure by Industry 
Table 1:

Establishment Size and Incorporation Rates: Industry Averages,

Massachusetts, 1875

(Panel A)

\begin{tabular}{|c|c|c|c|c|c|}
\hline & \multicolumn{2}{|c|}{$\begin{array}{c}\text { All } \\
\text { Establishments }\end{array}$} & \multicolumn{2}{|c|}{ Corporations } & \multirow{4}{*}{$\begin{array}{c}\text { Incorporation } \\
\text { Rate }\end{array}$} \\
\hline & & Average & & Average & \\
\hline & $\mathrm{N}$ & Capital & $\mathrm{N}$ & Capital & \\
\hline & (1) & $(2)$ & (3) & $(4)$ & \\
\hline \multicolumn{6}{|l|}{ Clothing } \\
\hline Boots and Shoes & 1,461 & 12,795 & 12 & 125,707 & 0.01 \\
\hline Other Clothing & 1,088 & 8,442 & 23 & 202,174 & 0.02 \\
\hline \multicolumn{6}{|l|}{ Food and Tobacco } \\
\hline Food Preparations & 783 & 12,580 & 16 & 175,875 & 0.02 \\
\hline Liquors and Beverages & 155 & 26,802 & 1 & 150,000 & 0.01 \\
\hline Tobacco & 264 & 3,076 & 4 & 14,088 & 0.02 \\
\hline \multicolumn{6}{|l|}{ Instruments } \\
\hline Clocks and Watches & 14 & 132,425 & 3 & 588,533 & 0.21 \\
\hline Scientific Instruments and Appliances & 52 & 8,244 & 7 & 107,382 & 0.13 \\
\hline Musical Instruments and Materials & 71 & 54,163 & 8 & 122,363 & 0.11 \\
\hline \multicolumn{6}{|l|}{ Metals, Metallic Goods, and Machinery } \\
\hline Agricultural Implements & 38 & 30,118 & 6 & 190,833 & 0.16 \\
\hline Arms and Ammunition & 20 & 48,215 & 1 & 9,398 & 0.05 \\
\hline Artisans' Tools & 124 & 17,956 & 12 & 118,133 & 0.10 \\
\hline Machines and Machinery & 311 & 44,565 & 69 & 157,666 & 0.22 \\
\hline Other Metals and Metallic Goods & 768 & 28,526 & 87 & 171,375 & 0.11 \\
\hline \multicolumn{6}{|l|}{ Oils and Chemicals } \\
\hline Chemical Preparations & 9 & 34,644 & 6 & 106,935 & 0.67 \\
\hline Fertilizers & 9 & 136,722 & 2 & 218,000 & 0.22 \\
\hline Oils and Illuminating Fluids & 33 & 69,311 & 7 & 112,929 & 0.21 \\
\hline Paints and Colors & 20 & 55,790 & 2 & 35,500 & 0.10 \\
\hline \multicolumn{6}{|l|}{ Paper and Paper Goods } \\
\hline Paper & 120 & 90,502 & 38 & 119,314 & 0.32 \\
\hline Printing and Publishing & 533 & 12,033 & 11 & 69,755 & 0.02 \\
\hline \multicolumn{6}{|l|}{ Textiles } \\
\hline Carpetings & 24 & 160,665 & 6 & 520,567 & 0.25 \\
\hline Cotton Goods & 220 & 290,203 & 107 & 449,478 & 0.49 \\
\hline Linen & 5 & 184,800 & 2 & 550,000 & 0.40 \\
\hline Print Works & 9 & 285,556 & 5 & 185,200 & 0.56 \\
\hline Silk & 6 & 81,333 & 1 & 120,000 & 0.17 \\
\hline Woolen Goods & 183 & 94,044 & 32 & 198,005 & 0.17 \\
\hline Other Textiles & 28 & 169,700 & 15 & 140,173 & 0.54 \\
\hline
\end{tabular}


Table 1, Continued:

Establishment Size and Incorporation Rates: Industry Averages, Massachusetts, 1875

\section{(Panel B)}

\begin{tabular}{|c|c|c|c|c|c|}
\hline & Est & $\begin{array}{l}\text { All } \\
\text { shments }\end{array}$ & & ations & \\
\hline & & Average & & Average & Incorporation \\
\hline & $\mathrm{N}$ & Capital & $\mathrm{N}$ & Capital & Rate \\
\hline & (1) & $(2)$ & (3) & $(4)$ & (5) \\
\hline Vessels and Carriages & & & & & \\
\hline Carriages and Wagons & 356 & 6,777 & 1 & 84,000 & 0.00 \\
\hline Vessels & 163 & 5,733 & 1 & 350,000 & 0.01 \\
\hline Wooden Goods & & & & & \\
\hline Furniture & 294 & 16,836 & 6 & 237,807 & 0.02 \\
\hline Lumber & 579 & 4,697 & 7 & 35,971 & 0.01 \\
\hline Other Wooden Goods & 460 & 9,728 & 10 & 67,975 & 0.02 \\
\hline Other Industries & & & & & \\
\hline Bricks & 104 & 15,939 & 9 & 186,222 & 0.09 \\
\hline Glass & 13 & 119,615 & 8 & 247,963 & 0.62 \\
\hline Jute & 6 & 72,833 & 3 & 119,000 & 0.50 \\
\hline Leather & 495 & 16,969 & 10 & 164,110 & 0.02 \\
\hline Rubber & 23 & 151,509 & 4 & 115,000 & 0.17 \\
\hline Stone & 151 & 11,020 & 21 & 90,468 & 0.14 \\
\hline Miscellaneous & & & & & \\
\hline Miscellaneous Manufactures & 1250 & 21,396 & 37 & 113,103 & 0.03 \\
\hline
\end{tabular}


Table 2: Industry Characteristics

\begin{tabular}{lcccc}
\hline \hline & Mean & SD & Min & Max \\
\hline Incorporation rate & 0.178 & 0.193 & 0 & 0.670 \\
& & & & \\
Capital & & & & \\
$\quad$ Log capital & 10.340 & 1.270 & 8.031 & 12.578 \\
Capital-output ratio & 0.618 & 0.305 & 0.171 & 1.497 \\
Steam engines per establishment & 0.342 & 0.253 & 0 & 0.889 \\
Fraction assets machines and buildings & 0.589 & 0.133 & 0.388 & 0.933 \\
& & & & \\
Labor & & & & \\
$\quad$ Log total employees & 3.286 & 1.208 & 1.220 & 5.873 \\
Fraction workforce female & 0.215 & 0.238 & 0 & 0.815 \\
Log annual wage, all employees & 6.273 & 0.273 & 5.521 & 6.764 \\
Log annual wage, adult male employees & 6.381 & 0.211 & 5.727 & 6.782 \\
& & & & \\
Growth rate of output, '65-'75 & 0.433 & 0.699 & -0.849 & 2.020 \\
\hline
\end{tabular}


Table 3: Determinants of Industry Incorporation Rates

\begin{tabular}{|c|c|c|c|c|c|c|c|}
\hline & (1) & $(2)$ & (3) & $(4)$ & (5) & (6) & (7) \\
\hline \multicolumn{8}{|c|}{ A: Univariate regressions } \\
\hline Capital-output ratio & $\begin{array}{l}0.236 * * \\
(0.086)\end{array}$ & & & & & & \\
\hline Steam engines per establishment & & $\begin{array}{c}0.492^{* *} \\
(0.116)\end{array}$ & & & & & \\
\hline Fraction assets machines and bldgs & & & $\begin{array}{c}0.596^{*} \\
(0.235)\end{array}$ & & & & \\
\hline Percent workforce female & & & & $\begin{array}{c}0.230 \\
(0.137)\end{array}$ & & & \\
\hline Log wage, all employees & & & & & $\begin{array}{c}-0.322^{* *} \\
(0.086)\end{array}$ & & \\
\hline Log wage, adult male employees & & & & & & $\begin{array}{c}-0.368^{* *} \\
(0.123)\end{array}$ & \\
\hline Growth rate of output, '65-'75 & & & & & & & $\begin{array}{c}-0.083+ \\
(0.046)\end{array}$ \\
\hline Constant & $\begin{array}{c}0.0364 \\
(0.0542)\end{array}$ & $\begin{array}{l}-0.0065 \\
(0.0324)\end{array}$ & $\begin{array}{l}-0.166 \\
(0.136)\end{array}$ & $\begin{array}{c}0.137 * * \\
(0.0433)\end{array}$ & $\begin{array}{l}2.196 * * \\
(0.540)\end{array}$ & $\begin{array}{l}2.521^{* *} \\
(0.792)\end{array}$ & $\begin{array}{c}0.195^{* *} \\
(0.0409)\end{array}$ \\
\hline R-squared & 0.138 & 0.475 & 0.156 & 0.077 & 0.202 & 0.158 & 0.113 \\
\hline \multicolumn{8}{|c|}{ B: Controlling for average firm scale } \\
\hline Capital-output ratio & $\begin{array}{c}0.090 \\
(0.069)\end{array}$ & & & & & & \\
\hline Steam engines per establishment & & $\begin{array}{l}0.368^{*} \\
(0.146)\end{array}$ & & & & & \\
\hline Fraction assets machines and bldgs & & & $\begin{array}{l}0.373+ \\
(0.213)\end{array}$ & & & & \\
\hline Percent workforce female & & & & $\begin{array}{l}-0.058 \\
(0.120)\end{array}$ & & & \\
\hline Log wage, all employees & & & & & $\begin{array}{l}-0.140 \\
(0.099)\end{array}$ & & \\
\hline Log wage, adult male employees & & & & & & $\begin{array}{l}-0.214^{*} \\
(0.099)\end{array}$ & \\
\hline Growth rate of output, '65-'75 & & & & & & & $\begin{array}{c}-0.018 \\
(0.028)\end{array}$ \\
\hline Log total employees & $\begin{array}{c}0.098 * * \\
(0.016)\end{array}$ & $\begin{array}{l}0.053^{*} \\
(0.021)\end{array}$ & $\begin{array}{l}0.099 * * \\
(0.020)\end{array}$ & $\begin{array}{l}0.112^{* *} \\
(0.018)\end{array}$ & $\begin{array}{l}0.096^{* *} \\
(0.020)\end{array}$ & $\begin{array}{l}0.100 * * \\
(0.018)\end{array}$ & $\begin{array}{l}0.103^{* *} \\
(0.015)\end{array}$ \\
\hline Constant & $\begin{array}{c}-0.199 * * \\
(0.055)\end{array}$ & $\begin{array}{c}-0.132 * * \\
(0.042)\end{array}$ & $\begin{array}{c}-0.362^{* *} \\
(0.088)\end{array}$ & $\begin{array}{c}-0.174^{* *} \\
(0.048)\end{array}$ & $\begin{array}{c}0.747 \\
(0.648)\end{array}$ & $\begin{array}{c}1.223+ \\
(0.639)\end{array}$ & $\begin{array}{c}-0.170 * * \\
(0.045)\end{array}$ \\
\hline $\begin{array}{r}\text { R-squared } \\
\text { Observations }\end{array}$ & $\begin{array}{c}0.459 \\
38\end{array}$ & $\begin{array}{c}0.561 \\
35\end{array}$ & $\begin{array}{c}0.504 \\
35\end{array}$ & $\begin{array}{c}0.444 \\
36\end{array}$ & $\begin{array}{c}0.450 \\
33\end{array}$ & $\begin{array}{c}0.469 \\
33\end{array}$ & $\begin{array}{c}0.574 \\
34\end{array}$ \\
\hline
\end{tabular}

Robust standard errors in parentheses

$* * \mathrm{p}<0.01, * \mathrm{p}<0.05,+\mathrm{p}<0.1$ 
Table 4:

Ownership of Manufacturing Corporations

\begin{tabular}{lccccc}
\hline \hline & Mean & Median & SD & Min & Max \\
\hline A. All Manufacturing Corporations & & & & & \\
Total paid-in capital & 210,638 & 100,000 & 323,753 & 1,000 & $2,500,000$ \\
Total shareholders & 47 & 18 & 87 & 2 & 730 \\
Board size & 4.06 & 4 & 1.44 & 2 & 13 \\
Percent owned by directors & 0.45 & 0.44 & 0.29 & 0.01 & 1 \\
Percent held by largest shareholder & 0.28 & 0.24 & 0.21 & 0.01 & 0.99 \\
Widely held & 0.42 & 0 & 0.49 & 0 & 1 \\
& & & & & \\
& & & & & \\
B. Manufacturing Corporations Traded on Boston Stock Exchange & & & \\
Total paid-in capital & & & & & \\
Total shareholders & 912,742 & 750,000 & 589,363 & 100,000 & $2,500,000$ \\
Board size & 261 & 237 & 182 & 60 & 730 \\
Percent owned by directors & 4.90 & 5 & 1.08 & 3 & 7 \\
Percent held by largest shareholder & 0.10 & 0.07 & 0.06 & 0.02 & 0.26 \\
Widely held & 0.07 & 0.05 & 0.07 & 0.01 & 0.36 \\
& 0.97 & 1 & 0.18 & 0 & 1 \\
\hline
\end{tabular}


Table 5:

Corporate Ownership: Industry Averages,

Massachusetts, 1875

\section{(Panel A)}

\begin{tabular}{|c|c|c|c|c|c|}
\hline & $\begin{array}{l}\text { Total } \\
\text { Capital }\end{array}$ & $\begin{array}{c}\text { Total } \\
\text { Share- } \\
\text { Holders }\end{array}$ & $\begin{array}{l}\text { Share } \\
\text { Owned by } \\
\text { Directors }\end{array}$ & $\begin{array}{l}\text { Largest } \\
\text { Stake } \\
\text { Held }\end{array}$ & $\begin{array}{c}\text { Share } \\
\text { Widely } \\
\text { Held }\end{array}$ \\
\hline \multicolumn{6}{|l|}{ Clothing } \\
\hline Boots and Shoes & 125,707 & 25 & 0.48 & 0.28 & 0.44 \\
\hline Other Clothing & 202,174 & 64 & 0.42 & 0.24 & 0.43 \\
\hline \multicolumn{6}{|l|}{ Food and Tobacco } \\
\hline Food Preparations & 175,875 & 32 & 0.32 & 0.17 & 0.62 \\
\hline Tobacco & 14,088 & 8 & 0.66 & 0.15 & 1.00 \\
\hline \multicolumn{6}{|l|}{ Instruments } \\
\hline Scientific Instruments and Appliances & 107,382 & 25 & 0.60 & 0.37 & 0.00 \\
\hline Musical Instruments and Materials & 122,363 & 10 & 0.56 & 0.29 & 0.20 \\
\hline \multicolumn{6}{|l|}{ Metals and Metallic Goods } \\
\hline Agricultural Implements & 190,833 & 54 & 0.43 & 0.22 & 0.40 \\
\hline Arms and Ammunition & 9,398 & 7 & 0.71 & 0.63 & 0.00 \\
\hline Artisans' Tools & 118,133 & 68 & 0.40 & 0.31 & 0.29 \\
\hline Machines and Machinery & 157,666 & 26 & 0.52 & 0.28 & 0.27 \\
\hline Other Metals and Metallic Goods & 171,375 & 25 & 0.45 & 0.29 & 0.40 \\
\hline \multicolumn{6}{|l|}{ Oils and Chemicals } \\
\hline Chemical Preparations & 89,076 & 25 & 0.40 & 0.28 & 0.25 \\
\hline Fertilizers & 218,000 & 30 & 0.41 & 0.41 & 0.50 \\
\hline Oils and Illuminating Fluids & 112,929 & 27 & 0.52 & 0.21 & 0.40 \\
\hline Paints and Colors & 35,500 & 16 & 0.27 & 0.27 & 0.25 \\
\hline \multicolumn{6}{|l|}{ Paper and Paper Goods } \\
\hline Paper & 119,314 & 22 & 0.58 & 0.37 & 0.22 \\
\hline Print Works & 185,200 & 12 & 0.66 & 0.48 & 0.25 \\
\hline Printing and Publishing & 69,755 & 18 & 0.72 & 0.42 & 0.17 \\
\hline \multicolumn{6}{|l|}{ Textiles } \\
\hline Carpetings & 520,567 & 113 & 0.41 & 0.26 & 0.50 \\
\hline Cotton Goods & 449,478 & 100 & 0.41 & 0.27 & 0.53 \\
\hline Linen & 550,000 & 36 & 0.55 & 0.41 & 0.00 \\
\hline Woolen Goods & 198,005 & 39 & 0.54 & 0.31 & 0.28 \\
\hline Other Textiles & 140,173 & 17 & 0.51 & 0.32 & 0.31 \\
\hline
\end{tabular}


Table 5:

Corporate Ownership: Industry Averages,

Massachusetts, 1875

\section{(Panel B)}

\begin{tabular}{|c|c|c|c|c|c|}
\hline & $\begin{array}{c}\text { Total } \\
\text { Capital }\end{array}$ & $\begin{array}{c}\text { Total } \\
\text { Share- } \\
\text { Holders }\end{array}$ & $\begin{array}{l}\text { Share } \\
\text { Owned by } \\
\text { Directors }\end{array}$ & $\begin{array}{c}\text { Largest } \\
\text { Stake } \\
\text { Held }\end{array}$ & $\begin{array}{c}\text { Share } \\
\text { Widely } \\
\text { Held }\end{array}$ \\
\hline \multicolumn{6}{|l|}{ Vessels and Carriages } \\
\hline Carriages and Wagons & 84,000 & 6 & 0.91 & 0.39 & 0.00 \\
\hline Vessels & 350,000 & 42 & 0.45 & 0.23 & 0.50 \\
\hline \multicolumn{6}{|l|}{ Wooden Goods } \\
\hline Furniture & 237,807 & 15 & 0.59 & 0.43 & 0.00 \\
\hline Lumber & 35,971 & 13 & 0.56 & 0.30 & 0.50 \\
\hline Other Wooden Goods & 67,975 & 35 & 0.56 & 0.26 & 0.50 \\
\hline \multicolumn{6}{|l|}{ Other Industries } \\
\hline Brick & 186,222 & 35 & 0.44 & 0.27 & 0.50 \\
\hline Glass & 247,963 & 109 & 0.25 & 0.22 & 0.57 \\
\hline Jute & 119,000 & 14 & 0.49 & 0.28 & 0.33 \\
\hline Leather & 164,110 & 41 & 0.47 & 0.33 & 0.25 \\
\hline Rubber & 115,000 & 19 & 0.35 & 0.29 & 0.00 \\
\hline Stone & 119,194 & 31 & 0.44 & 0.31 & 0.43 \\
\hline \multicolumn{6}{|l|}{ Miscellaneous } \\
\hline Miscellaneous Manufactures & 113,103 & 29 & 0.36 & 0.20 & 0.61 \\
\hline
\end{tabular}


Table 6: Determinants of Ownership Structures

\begin{tabular}{|c|c|c|c|c|}
\hline & \multicolumn{4}{|c|}{ Dependent Variable: } \\
\hline & $\begin{array}{c}\text { Log Total } \\
\text { Shareholders } \\
(1)\end{array}$ & $\begin{array}{c}\text { Fraction } \\
\text { Owned by } \\
\text { Directors } \\
(2) \\
\end{array}$ & $\begin{array}{l}\text { Board } \\
\text { Size } \\
(3) \\
\end{array}$ & $\begin{array}{l}\text { Largest } \\
\text { Stake } \\
\text { Held } \\
(4) \\
\end{array}$ \\
\hline Steam engines per establishment & $\begin{array}{l}-0.581^{*} \\
(0.249)\end{array}$ & $\begin{array}{c}0.105+ \\
(0.0526)\end{array}$ & $\begin{array}{c}-0.616+ \\
(0.313)\end{array}$ & $\begin{array}{l}0.0860+ \\
(0.0459)\end{array}$ \\
\hline Log paid-in capital & $\begin{array}{c}0.449^{* *} \\
(0.0859)\end{array}$ & $\begin{array}{c}-0.0558 * * \\
(0.0163)\end{array}$ & $\begin{array}{c}0.224 * * \\
(0.0592)\end{array}$ & $\begin{array}{l}-0.0257^{*} \\
(0.00945)\end{array}$ \\
\hline Constant & $\begin{array}{l}-1.969 * \\
(0.949)\end{array}$ & $\begin{array}{l}1.065^{* *} \\
(0.187)\end{array}$ & $\begin{array}{l}1.701^{* *} \\
(0.597)\end{array}$ & $\begin{array}{l}0.544^{* *} \\
(0.113)\end{array}$ \\
\hline $\begin{array}{r}\text { Observations } \\
\text { R-squared }\end{array}$ & $\begin{array}{c}459 \\
0.291\end{array}$ & $\begin{array}{c}461 \\
0.142\end{array}$ & $\begin{array}{c}461 \\
0.093\end{array}$ & $\begin{array}{c}460 \\
0.105\end{array}$ \\
\hline Log wage, adult male employees & $\begin{array}{l}0.689 * \\
(0.269)\end{array}$ & $\begin{array}{l}-0.135^{*} \\
(0.0511)\end{array}$ & $\begin{array}{l}0.583+ \\
(0.334)\end{array}$ & $\begin{array}{l}-0.123 * * \\
(0.0357)\end{array}$ \\
\hline Log paid-in capital & $\begin{array}{c}0.467^{* *} \\
(0.0918)\end{array}$ & $\begin{array}{c}-0.0579 * * \\
(0.0182)\end{array}$ & $\begin{array}{c}0.231^{* *} \\
(0.0639)\end{array}$ & $\begin{array}{l}-0.0267 * \\
(0.0108)\end{array}$ \\
\hline Constant & $\begin{array}{c}-6.829 * * \\
(2.161)\end{array}$ & $\begin{array}{l}1.997 * * \\
(0.425)\end{array}$ & $\begin{array}{l}-2.375 \\
(2.563)\end{array}$ & $\begin{array}{l}1.372^{* *} \\
(0.279)\end{array}$ \\
\hline $\begin{array}{r}\text { Observations } \\
\text { R-squared }\end{array}$ & $\begin{array}{c}453 \\
0.289\end{array}$ & $\begin{array}{c}455 \\
0.138\end{array}$ & $\begin{array}{c}455 \\
0.086\end{array}$ & $\begin{array}{c}454 \\
0.106\end{array}$ \\
\hline Fraction workforce female & $\begin{array}{l}-0.163 \\
(0.238)\end{array}$ & $\begin{array}{c}0.0945^{*} \\
(0.0398)\end{array}$ & $\begin{array}{l}-0.224 \\
(0.297)\end{array}$ & $\begin{array}{l}0.0715+ \\
(0.0371)\end{array}$ \\
\hline Log paid-in capital & $\begin{array}{c}0.452^{* *} \\
(0.0884)\end{array}$ & $\begin{array}{c}-0.0589 * * \\
(0.0176)\end{array}$ & $\begin{array}{c}0.216^{* *} \\
(0.0651)\end{array}$ & $\begin{array}{c}-0.0266^{*} \\
(0.0109)\end{array}$ \\
\hline Constant & $\begin{array}{l}-2.258^{*} \\
(0.989)\end{array}$ & $\begin{array}{l}1.127 * * \\
(0.203)\end{array}$ & $\begin{array}{c}1.549^{*} \\
(0.687)\end{array}$ & $\begin{array}{l}0.578 * * \\
(0.127)\end{array}$ \\
\hline $\begin{array}{r}\text { Observations } \\
\text { R-squared }\end{array}$ & $\begin{array}{c}464 \\
0.282 \\
\end{array}$ & $\begin{array}{c}466 \\
0.136 \\
\end{array}$ & $\begin{array}{c}466 \\
0.079 \\
\end{array}$ & $\begin{array}{c}465 \\
0.096 \\
\end{array}$ \\
\hline
\end{tabular}

Robust standard errors, adjusted for clustering by firm county, in parentheses.

All specifications include county fixed effects.

$* * \mathrm{p}<0.01, * \mathrm{p}<0.05,+\mathrm{p}<0.1$ 
Table 7: Determinants of Ownership Structures

\begin{tabular}{|c|c|c|c|c|}
\hline & \multicolumn{4}{|c|}{ Dependent Variable: } \\
\hline & $\begin{array}{c}\text { Log Total } \\
\text { Shareholders } \\
\text { (1) }\end{array}$ & $\begin{array}{l}\text { Fraction } \\
\text { Owned by } \\
\text { Directors } \\
(2)\end{array}$ & $\begin{array}{l}\text { Board } \\
\text { Size } \\
(3)\end{array}$ & $\begin{array}{l}\text { Largest } \\
\text { Stake } \\
\text { Held } \\
(4) \\
\end{array}$ \\
\hline Steam engines per establishment & $\begin{array}{l}-0.650 * \\
(0.260)\end{array}$ & $\begin{array}{c}0.106+ \\
(0.0540)\end{array}$ & $\begin{array}{c}-0.606+ \\
(0.313)\end{array}$ & $\begin{array}{l}0.0860+ \\
(0.0463)\end{array}$ \\
\hline Log paid-in capital & $\begin{array}{c}0.416^{* *} \\
(0.0815)\end{array}$ & $\begin{array}{c}-0.0512 * * \\
(0.0159)\end{array}$ & $\begin{array}{c}0.244^{* *} \\
(0.0642)\end{array}$ & $\begin{array}{l}-0.0252 * \\
(0.0100)\end{array}$ \\
\hline Log firm age & $\begin{array}{c}0.138 * * \\
(0.0432)\end{array}$ & $\begin{array}{l}-0.0142 \\
(0.0113)\end{array}$ & $\begin{array}{l}-0.0706 \\
(0.0587)\end{array}$ & $\begin{array}{c}-0.000689 \\
(0.00677)\end{array}$ \\
\hline Constant & $\begin{array}{l}-1.818+ \\
(0.904)\end{array}$ & $\begin{array}{l}1.039 * * \\
(0.183)\end{array}$ & $\begin{array}{c}1.610 * \\
(0.624)\end{array}$ & $\begin{array}{c}0.539 * * \\
(0.116)\end{array}$ \\
\hline $\begin{array}{r}\text { Observations } \\
\text { R-squared }\end{array}$ & $\begin{array}{c}455 \\
0.308\end{array}$ & $\begin{array}{c}457 \\
0.143\end{array}$ & $\begin{array}{c}457 \\
0.097\end{array}$ & $\begin{array}{c}456 \\
0.103\end{array}$ \\
\hline Log wage, adult male employees & $\begin{array}{l}0.815^{* *} \\
(0.283)\end{array}$ & $\begin{array}{l}-0.156 * * \\
(0.0526)\end{array}$ & $\begin{array}{c}0.482 \\
(0.359)\end{array}$ & $\begin{array}{l}-0.131 * * \\
(0.0379)\end{array}$ \\
\hline Log paid-in capital & $\begin{array}{c}0.438 * * \\
(0.0883)\end{array}$ & $\begin{array}{c}-0.0539 * * \\
(0.0180)\end{array}$ & $\begin{array}{c}0.250 * * \\
(0.0699)\end{array}$ & $\begin{array}{c}-0.0260^{*} \\
(0.0113)\end{array}$ \\
\hline Log firm age & $\begin{array}{c}0.132^{* *} \\
(0.0441)\end{array}$ & $\begin{array}{l}-0.0147 \\
(0.0107)\end{array}$ & $\begin{array}{l}-0.0733 \\
(0.0585)\end{array}$ & $\begin{array}{l}-0.00281 \\
(0.00691)\end{array}$ \\
\hline Constant & $\begin{array}{c}-7.533^{* *} \\
(2.199)\end{array}$ & $\begin{array}{l}2.109 * * \\
(0.430)\end{array}$ & $\begin{array}{l}-1.797 \\
(2.711)\end{array}$ & $\begin{array}{l}1.426^{* *} \\
(0.283)\end{array}$ \\
\hline $\begin{array}{l}\text { Observations } \\
\text { R-squared }\end{array}$ & $\begin{array}{c}449 \\
0.304\end{array}$ & $\begin{array}{c}451 \\
0.140\end{array}$ & $\begin{array}{c}451 \\
0.089\end{array}$ & $\begin{array}{c}450 \\
0.105\end{array}$ \\
\hline Fraction workforce female & $\begin{array}{l}-0.187 \\
(0.251)\end{array}$ & $\begin{array}{c}0.0972^{*} \\
(0.0409)\end{array}$ & $\begin{array}{l}-0.202 \\
(0.297)\end{array}$ & $\begin{array}{c}0.0727+ \\
(0.0380)\end{array}$ \\
\hline Log paid-in capital & $\begin{array}{c}0.421^{* *} \\
(0.0856)\end{array}$ & $\begin{array}{c}-0.0545^{* *} \\
(0.0174)\end{array}$ & $\begin{array}{l}0.239 * * \\
(0.0722)\end{array}$ & $\begin{array}{c}-0.0260^{*} \\
(0.0115)\end{array}$ \\
\hline Log firm age & $\begin{array}{c}0.120^{* *} \\
(0.0424)\end{array}$ & $\begin{array}{l}-0.0132 \\
(0.0103)\end{array}$ & $\begin{array}{l}-0.0802 \\
(0.0584)\end{array}$ & $\begin{array}{l}-0.00128 \\
(0.00639)\end{array}$ \\
\hline Constant & $\begin{array}{l}-2.120 * \\
(0.957)\end{array}$ & $\begin{array}{l}1.101^{* *} \\
(0.200)\end{array}$ & $\begin{array}{l}1.435+ \\
(0.722)\end{array}$ & $\begin{array}{l}0.573^{* *} \\
(0.130)\end{array}$ \\
\hline $\begin{array}{r}\text { Observations } \\
\text { R-squared }\end{array}$ & $\begin{array}{c}460 \\
0.296 \\
\end{array}$ & $\begin{array}{c}462 \\
0.138 \\
\end{array}$ & $\begin{array}{c}462 \\
0.083 \\
\end{array}$ & $\begin{array}{c}461 \\
0.095 \\
\end{array}$ \\
\hline
\end{tabular}

Robust standard errors, adjusted for clustering by firm county, in parentheses.

All specifications include county fixed effects.

** $\mathrm{p}<0.01, * \mathrm{p}<0.05,+\mathrm{p}<0.1$ 